\title{
Leadership Styles Prevailing for Faculty Members at the College of Education in Al-Delam from the Point of View of its Female Students
}

\author{
Thikryat Jibril Qaralleh ${ }^{1}$ \\ ${ }^{1}$ Department of Educational Sciences, College of Education AlDelam, Prince Sattam bin Abdulaziz University, \\ AlKharj, Saudi Arabia \\ Correspondence: Thikryat Jibril Qaralleh, Department of Educational Sciences, College of Education Al-Delam, \\ Prince Sattam bin Abdulaziz University, AlKharj, Saudi Arabia.
}

Received: December 22, 2019

Accepted: January 16, 2020

Online Published: January 17, 2020

doi:10.5430/ijhe.v9n2p167

URL: https://doi.org/10.5430/ijhe.v9n2p167

\begin{abstract}
The current study aimed to get acquainted with the students' point of view of the leadership styles practiced by the faculty members at Prince Sattam bin Abdulaziz University" College of Education in Dammam as a model "and to know if there were differences in the response of female students to the fields of the study tool according to the difference in the study variables". The study adopted descriptive research, field analysis and a questionnaire consisting of "the autocratic style, democratic stratification, and the facilitative style" was developed distributed to a sample of $(31 \%)$. The findings of the study showed that the general arithmetic mean for the responses of the sample members to the paragraphs that measure the prevailing leadership styles of the faculty members from the point of view of its students has come with an average degree of appreciation and the democratic style has ranked first, followed by the second autocratic style and finally the facilitative style. The results also showed that there were no statistically significant differences in the field of (democratic style) due to the age that female students from different age groups agree that faculty members practice a democratic style. Finally, the results showed that there are statistically significant differences between the values of the arithmetic mean for the responses of the sample members towards the questionnaires of the study tool according to the variable of the type of department on the tool as a whole. The study made several recommendations, including: Urging the faculty members to practice the democratic leadership style and to avoid the practice of the authoritarian leadership style.
\end{abstract}

Keywords: educational styles, leaders, democratic leadership, autocratic leadership, Saudi Arabia

\section{Introduction}

Interest in the study of leadership has received the attention of researchers based on the importance of leadership and its complex and interrelated processes. Administrative leadership is the main driver of the effectiveness of any organization because the leader is the one who can harness and mobilize existing and potential energies. Leadership is a global human phenomenon, it aims to improve organizational capacity, solve problems and establish positive relationships. This is evident through the role of academic leaders in universities and the exercise of the appropriate leadership style that contributes to the achievement of the tasks of universities, teaching and scientific research and community service (Mahjoub, 2003). Universities are one of the most important institutions that work to create and prepare human resources that respond to the requirements of comprehensive social development through the preparation and provide them with the knowledge and skills that help them to. Universities also contribute to the development of students' personalities in all aspects and prepare them and train them scientifically, technically and literally (Payteres, 2003). The concept of productivity was linked to the commitment of the leader to the public interest and the involvement of subordinates in solving problems and possessing human, intellectual and technical skills. Leadership is indispensable for rationalizing the behavior of individuals and bringing about changes that arise from the elements of initiative, expectation, innovation and the realization of the needs of employees in the institution in Taweel (2003).

Previous studies such as al-Shatnawi and al-Ghamdi (2016) and al-Fraihat (2018) identify lack of studies within the limits of the researcher's knowledge that dealt with these styles at Prince Sattam bin Abdulaziz University. This study identifies its problem in answering the following questions: 
1. What are the prevailing leadership styles of the faculty members at the College of Education in Delam from the point of view of its female students?

2. Are there any significant differences at the level of significance $(\alpha \leq 0.05)$ between the mean of the study sample in the prevailing leadership styles of the faculty of education in Delam from the point of view of its female students (academic level, department type)?

Dahesh (2016) defined leadership as "the best way to interact between human, material and money with maximum productivity and the lowest possible costs and within the time set to achieve the goal." It is defined procedurally as a process of mutual influence between human and material resources to achieve a set of enterprise objectives. Arabiyat (2012) defined leadership style as the "administrative trend that predominantly follows the President in his various practices and behaviors with subordinates, and represents a semi-permanent strategy of his behavior with them." It is procedurally defined as the diversity of behavior followed by the president in the institution with his subordinates.

The research contributes to the existing knowledge in a way that there are no studies available in the literature which cover these aspects specially in English language. So, this research is an attempt to introduce Arabian work culture to the rest of the world.

\section{Literature Review}

Ford (1998) aimed to reveal the leadership styles of deans of colleges and universities in Western Australia as seen by faculty members, the results of the study pointed to the prevalence of three leadership styles: Democratic, concessional, and authoritarian. Brown (1999) entitled comparison of the perception of the heads of universities and colleges on effective leadership practices, which aimed to examine the perception of effective leadership among the heads of colleges and universities by type of institution, race, sex and the number of years of experience. Significant differences due to the type of institution and the number of years of experience and the existence of significant differences between races and between ages. Giambri (2003) aimed to identify the viewpoint of management and employees of the role of leadership style in organizational effectiveness, as the results showed that: There are leadership styles to clarify the tasks before the participants, the study also showed that the perceptions of the administrative and functional system towards the style of leadership and performance of the best institutions They were medium and performance was increased through the use of democratic leadership. Ashour (2012) aimed to identify the degree of faculty members' perception of the leadership style practiced by the academic department heads at Yarmouk University and to identify the impact of gender variables, scientific rank, and type of college in their perceptions. The study population consisted of (750) members where a simple stratified random sample was selected. The study reached the following results: The leadership style practiced by the heads of departments at Yarmouk University is the democratic leadership style and to a large extent, followed by the authoritarian leadership style. The study shows that there are no statistically significant differences in the degree of faculty members' perception of the leadership style practiced by the academic department heads at Yarmouk University from the point of view of the sample of the study attributed to the gender variable, scientific rank and the type of the college.

Arabeyat (2012) aims to identify the styles of educational leadership prevailing among the heads of academic departments at the Balqa Applied University, and its impact on the performance of faculty members, a questionnaire designed specifically for the purposes of this study, and consists of four areas to measure the prevailing leadership styles. The study population consists of (222) faculty members at Al-Balqa Applied University / College of Technological Engineering. The study found a high level of performance among faculty members and found that there is an impact of the two types of leadership: Democratic and missionary on the performance of workers, and the absence of the impact of the traditional and authoritarian leadership styles on the performance of staff, and in the light of these results recommended that the need for intensive training of heads of academic departments Upon receiving their positions; in order to spread awareness and knowledge of the importance of using different leadership styles, and the impact of each on the performance of workers under their leadership. Crimin (2013) aimed to identify the level of possession of academic leaders at Tafila Technical University in southern Jordan of leadership skills from the perspective of faculty members, and to achieve the objectives of the study the researcher prepared a questionnaire consisting of (41) paragraphs and distributed to the sample of the study consisting of (146) teachers. The results showed that the level of academic leaders 'skills of leadership behavior was moderate, and the results of the study showed that there were statistically significant differences in the level of academic leaders' skills of leadership behavior from the point of view of faculty members in Tafila Technical University according to sex and specialization variables, while not showing. Statistically significant differences according to the variable of experience or interaction of any of these variables. 
Al-Shatnawi and Al-Ghamdi (2016) study aims to determine the leadership style of the department heads at Al-Baha University from the perspective of faculty members. The descriptive method was used in its survey model. The sample of the study consisted of 282 members. The results of the study showed that the dominant leadership style among academic department heads was the democratic mode and a large degree of practice, followed by the second authoritarian mode with a low degree of practice, then came in the last tasbih style and a low degree of practice. While there were statistically significant differences in the estimates of the sample for the practice of the heads of departments of the democratic style due to the type of college and for the benefit of human faculties. Tahtouh (2016) aimed at identifying the impact of administrative leadership styles, "autocratic leadership style, democratic leadership style, free leadership style on the organizational citizenship behavior of the administrative staff at King Abdulaziz University in Jeddah." The sample of the study included 172 employees. The study showed many results, including the style of democratic leadership, followed by the style of free leadership, and then the style of autocratic leadership. The study also showed that there are no statistically significant differences in the styles of administrative leadership, and the behavior of organizational citizenship attributed to personal variables (age, educational qualification), and the most important recommendations of the study, strengthening the practice of democratic leadership style, and take corrective measures to practice the style of autocratic leadership, And free driving style. And make more efforts when nominating and selecting the appropriate administrative leaders according to fair and objective rules and standards. The study of Bani Issa and Al-Atari (2019) aimed to reveal the styles of behavior of leaders as perceived by faculty members working in public and private universities in the north of the Kingdom and its relationship to some variables such as sex, years of experience, academic rank, university sector, and college type. The descriptive approach was adopted, and the questionnaire was used as a tool distributed to a random stratified sample of (304) faculty members. There are statistically significant differences attributed to variables of years of experience and type of college.

The literature review suggests both types of qualitative and quantitative research approaches as well as descriptive and exploratory research designs. Likewise, the type of leadership style varies in influencing the followers depending upon the nature and extent of relationships between leaders and followers. The current study is similar to previous studies on the subject of leadership patterns prevailing in universities. It is also similar in the instrument used and differs in the respondent's level and type.

\section{Methods}

The study adopted to achieve its objectives through descriptive research. A comprehensive survey was conducted for all members of the study population and analyzed all data collected by answering the questionnaire. The study population consisted of all 1010 female students at the College of Education in Delam, Saudi Arabia, and the following Table 1 shows the distribution of the study population according to the study level:

Table 1. Distribution of study population by level of study

\begin{tabular}{cc}
\hline Level of study & Number of female students \\
\hline The first level & 18 \\
The second level & 65 \\
The third level & 87 \\
The fourth level & 163 \\
The fifth level & 214 \\
The sixth level & 196 \\
Seventh level & 148 \\
Eighth level & 119 \\
Total & 1010
\end{tabular}

A random sample $(31 \%)$ was selected from all population of study (313) students from all study levels. The questionnaire was distributed to them. A total of 300 questionnaires were valid for statistical analysis with a response rate of $95.8 \%$ of the total sample of $(29.7 \%)$ the study population. 
Table 2. The characteristics of the study sample according to their personal and functional variables

\begin{tabular}{cccc}
\hline Variable & Variable classes & Number & Percentage \\
\hline \multirow{3}{*}{ Section to which you belong } & Mathematics & 40 & 13.3 \\
& Home Economics & 36 & 12.0 \\
& Islamic studies & 155 & 51.7 \\
& Arabic Language & 69 & 23.0 \\
& First & 91 & 30.3 \\
& Second & 20 & 6.7 \\
Level of study & Third & 17 & 5.7 \\
& Fourth & 10 & 3.3 \\
& Fifth & 22 & 7.3 \\
& Sixth & 52 & 17.3 \\
& Seventh & 45 & 15.0 \\
Age & eighth & 43 & 14.3 \\
& $18-21$ & 132 & 44.0 \\
& $22-25$ & 133 & 44.3 \\
& 26 - 29 & 28 & 9.3 \\
& 30 and above & 7 & 2.3 \\
\hline
\end{tabular}

Data from the above Table 2 show that;

1. $51.7 \%$ of the female students (members of the study sample) study in the Department of Islamic Studies, compared to $(23.0 \%)$ of them in the Department of Arabic, and (13.3\%) study in the Department of Mathematics, and finally (12.0\%) of The total number of study sample is studied in the Department of Home Economics.

2. That $30.3 \%$ of the total sample of students female in the first level of study, and second place students female in the sixth level and constituted $17.3 \%$, followed by those in the seventh level (15.0\%), and then those who They study in the eighth level (14.3\%), then those in the fifth level (7.3\%), then those in the second level $(6.7 \%)$, then in the third level (5.7\%) and finally those who They study level fourth $\quad(3.3 \%)$ of the total sample.

3. As for the variable age, it was found that the age group (22-25 years) ranked first and constituted $44.3 \%$ of the total sample of the study. Then came the third age group (26-29 years) by $(9.3 \%)$, and finally the age group (30 years and above) by $2.3 \%$ ) of the total sample.

The respondents' responses to the questionnaires were categorized according to the Likert five-point scale and were determined by five responses according to their weight as follows: ( Very high degree was given five grades, and high degree was given four grades, medium grades, was given three grades, a few grades was two grades, very little grades was given one ). To ensure the sincerity of the study tool, it was presented to a number of faculty arbitrators with experience and competence in the subject of the study to verify the suitability of its paragraphs to the objectives that it seeks to achieve. To reach the final image of the questionnaire to suit the objectives of the current study and the validity of paragraphs and belonging to the dimensions that were designed for them. The reliability coefficient was extracted according to the Cronbach alpha equation to ensure the internal consistency in its final form for each variable in all dimensions. The value of the total validity coefficient was $(0.924)$ and it is high and indicates the consistency and consistency between the paragraphs of the tool. Following Table 3 shows the values of the stability coefficients of the independent and dependent study variables: 
Table 3. Stability coefficient value for internal consistency of study variables

\begin{tabular}{ccc}
\hline $\begin{array}{c}\text { Number of } \\
\text { questions }\end{array}$ & Leadership styles & $\begin{array}{c}\text { Reliability coefficient } \\
\text { (Cronbach Alpha) }\end{array}$ \\
\hline $1-13$ & Autocratic & 0.930 \\
$1-12$ & Democratic & 0.929 \\
$1-12$ & Facilitative & 0.952 \\
- & The tool as a whole & 0.924 \\
\hline
\end{tabular}

\section{Results and Discussion}

The results of the Table 4 indicate that the general arithmetic average of the responses of the sample to the paragraphs that measure the prevailing leadership styles of the faculty members at the College of Education in Delam from the point of view female students reached (3.09) and represents estimation degree medium. The democratic style came first with an arithmetic mean (4.02), followed by the Autocratic with an arithmetic average (2.72), and finally the negative style with an arithmetic average (2.56).

Table 4. Arithmetic averages and standard deviations to identify the responses of the respondents to the paragraphs that measure the leadership styles prevailing for faculty members at the College of Education in Delam from the point of view of its female students

\begin{tabular}{cccccc}
\hline $\begin{array}{c}\text { Domain } \\
\text { number }\end{array}$ & Name the style & Mean & $\begin{array}{c}\text { Standard } \\
\text { deviation }\end{array}$ & $\begin{array}{c}\text { Sorted by } \\
\text { average }\end{array}$ & $\begin{array}{c}\text { Level by } \\
\text { average }\end{array}$ \\
\hline 1 & Autocratic & 2.72 & 0.904 & 2 & medium \\
2 & Democratic & 4.02 & 0.725 & 1 & High \\
3 & Facilitative & 2.56 & 1.016 & 3 & medium \\
- & $\begin{array}{c}\text { General } \\
\text { arithmetic mean }\end{array}$ & 3.09 & 0.598 & - & medium
\end{tabular}

The following is a presentation of the arithmetic averages and standard deviations of the responses of the study sample on the areas that measure the leadership styles prevailing for the faculty members of the College of Education in Delam from the perspective of its students individually: 
Table 5. Arithmetic averages and standard deviations to identify responses of respondents to questionnaires that measure autocratic style

\begin{tabular}{|c|c|c|c|c|c|}
\hline Number & Questions & Mean & $\begin{array}{l}\text { Standard } \\
\text { deviation }\end{array}$ & $\begin{array}{l}\text { Sorted by } \\
\text { average }\end{array}$ & $\begin{array}{l}\text { Level by } \\
\text { average }\end{array}$ \\
\hline \multicolumn{6}{|c|}{ The university professor: } \\
\hline 1 & Obligate Students female at subject the course's plan & 3.68 & 1.105 & 1 & High \\
\hline 2 & $\begin{array}{l}\text { imposes her opinion strongly without paying attention to } \\
\text { the student's opinion }\end{array}$ & 2.71 & 1.257 & 6 & medium \\
\hline 3 & Limit human relations between them and students & 2.82 & 1.159 & 5 & medium \\
\hline 4 & $\begin{array}{l}\text { Prevent the involvement of female students an Determine } \\
\text { the time of the tests }\end{array}$ & 2.52 & 1.279 & 10 & medium \\
\hline 5 & Predominantly formal by appearance and behavior & 2.95 & 1.184 & 3 & medium \\
\hline 6 & $\begin{array}{c}\text { Suppressing student female when expressing her opinion } \\
\text { and her thoughts }\end{array}$ & 2.55 & 1.246 & 9 & medium \\
\hline 7 & $\begin{array}{l}\text { Follow the traditional system of teaching to remain in } \\
\text { control of classroom management }\end{array}$ & 2.84 & 1.265 & 4 & medium \\
\hline 8 & $\begin{array}{c}\text { Frustrates the student female who has the ability to } \\
\text { creativity and innovation }\end{array}$ & 2.14 & 1.155 & 13 & Low \\
\hline 9 & $\begin{array}{l}\text { relies on correcting test papers on the absolute } \\
\text { preservation of information }\end{array}$ & 2.68 & 1.271 & 7 & medium \\
\hline 10 & Ignore feedback data for the course & 2.56 & 1.162 & 8 & medium \\
\hline 11 & $\begin{array}{l}\text { tries to solve the problems of the female students by } \\
\text { herself, based on her personal view of the situation }\end{array}$ & 3.02 & 1.277 & 2 & medium \\
\hline 12 & $\begin{array}{l}\text { uses the threatening technique in degrees to suppress } \\
\text { female students }\end{array}$ & 2.50 & 1.328 & 11 & medium \\
\hline 13 & $\begin{array}{l}\text { Blame and excessive criticism of her female students } \\
\text { with each lecture }\end{array}$ & 2.44 & 1.256 & 12 & medium \\
\hline- & Domain as a whole & 2.72 & 0.904 & - & medium \\
\hline
\end{tabular}

It is clear from the results in the previous Table 5 that the average arithmetic of the answers of the respondents to the paragraphs that measure the autocratic style has reached (2.72) and represents an average grade, and came first paragraph (1) Paragraph (11) (attempting to solve the problems of the students themselves based on their personal view of the situation), and in the last place came paragraph (8) (frustrates the student who has the ability to creativity and innovation), and all paragraphs that measure that area was promoted low ratings and medium and high. 
Table 6. Arithmetic averages and standard deviations to identify responses of respondents to paragraphs that measure the democratic style

\begin{tabular}{|c|c|c|c|c|c|}
\hline Number & Questions & Mean & $\begin{array}{l}\text { Standard } \\
\text { deviation }\end{array}$ & $\begin{array}{c}\text { Sorted by } \\
\text { average }\end{array}$ & $\begin{array}{l}\text { Level by } \\
\text { average }\end{array}$ \\
\hline \multicolumn{6}{|c|}{ The university professor: } \\
\hline 1 & $\begin{array}{l}\text { Take into account the needs of students psychological, } \\
\text { social, cultural, emotional and others }\end{array}$ & 4.04 & 0.965 & 7 & High \\
\hline 2 & $\begin{array}{l}\text { characterized by objectivity during criticizing its female } \\
\text { students inside the classroom }\end{array}$ & 3.85 & 0.916 & 12 & High \\
\hline 3 & Show flexibility and easy in dealing with students & 4.05 & 0.977 & 5 & High \\
\hline 4 & Avoid bias for one student at the expense of the other & 3.88 & 1.092 & 11 & High \\
\hline 5 & $\begin{array}{l}\text { Open the door to dialogue with female students } \\
\text { regarding lectures }\end{array}$ & 4.14 & 0.927 & 1 & High \\
\hline 6 & $\begin{array}{l}\text { Take into account different perspectives when solving } \\
\text { problems }\end{array}$ & 3.98 & 0.966 & 9 & High \\
\hline 7 & $\begin{array}{l}\text { It works to strengthen the confidence between them and } \\
\text { the female students }\end{array}$ & 4.09 & 1.005 & 3 & High \\
\hline 8 & $\begin{array}{c}\text { Breed reassurance the student female while talking to } \\
\text { her }\end{array}$ & 4.06 & 0.978 & 4 & High \\
\hline 9 & $\begin{array}{l}\text { Accept constructive criticism from female students } \\
\text { regarding classroom situations }\end{array}$ & 3.99 & 0.954 & 8 & High \\
\hline 10 & $\begin{array}{l}\text { It instills the values of cooperation, friendliness and love } \\
\text { among its students }\end{array}$ & 4.05 & 0.868 & 6 & High \\
\hline 11 & $\begin{array}{l}\text { Accept visit her office by female students without office } \\
\text { hours }\end{array}$ & 3.93 & 1.048 & 10 & High \\
\hline 12 & $\begin{array}{l}\text { Guiding her female students for what is good for them at } \\
\text { the scientific and practical level. }\end{array}$ & 4.14 & 0.890 & 2 & High \\
\hline- & Domain as a whole & 4.02 & 0.725 & - & High \\
\hline
\end{tabular}

It is clear from the results in the previous Table 6 that the average arithmetic of the responses of the respondents to the paragraphs that measure the democratic style has reached (4.02) and represents a high degree of appreciation, and came first paragraph (5) (open the door to dialogue with students, including Concerning the lectures), followed by paragraph (12) (guiding students for what is good for them at the scientific and practical level), and in the last paragraph came paragraph (2) (characterized by objectivity in criticizing her students in the classroom), and I have stimulated all the paragraphs that It measures that area with high estimates. 
Table 7. Arithmetic averages and standard deviations to identify the responses of the respondents to the paragraphs that measure the Facilitative style

\begin{tabular}{|c|c|c|c|c|c|}
\hline Number & Paragraph & Mean & $\begin{array}{l}\text { Standard } \\
\text { deviation }\end{array}$ & $\begin{array}{l}\text { Sorted by } \\
\text { average }\end{array}$ & $\begin{array}{l}\text { Level by } \\
\text { average }\end{array}$ \\
\hline \multicolumn{6}{|c|}{ The university professor: } \\
\hline 1 & $\begin{array}{l}\text { her personality predominantly courtesies at the expense } \\
\text { of university work }\end{array}$ & 2.77 & 1.168 & 1 & Medium \\
\hline 2 & $\begin{array}{l}\text { Evade responsibility in embarrassing situations with } \\
\text { female students }\end{array}$ & 2.74 & 1.241 & 2 & Medium \\
\hline 3 & Leaves the freedom to the subjects for female students & 2.60 & 1.191 & 4 & Medium \\
\hline 4 & Make unwise decisions in advising students & 2.44 & 1.202 & 11 & Medium \\
\hline 5 & $\begin{array}{l}\text { Waste the time of the lecture at talk without the benefit } \\
\text { of female students }\end{array}$ & 2.59 & 1.273 & 5 & Medium \\
\hline 6 & $\begin{array}{l}\text { don't punctuality for lectures, which reflects negatively } \\
\text { on the commitment of female students to lectures }\end{array}$ & 2.54 & 1.301 & 6 & Medium \\
\hline 7 & $\begin{array}{l}\text { Hesitate to schedule the tests because she doesn't have } \\
\text { the ability to make a decision }\end{array}$ & 2.29 & 1.219 & 12 & Low \\
\hline 8 & $\begin{array}{l}\text { Depend on the student female to explain the parts of the } \\
\text { lecture without guidance by her }\end{array}$ & 2.50 & 1.315 & 8 & Medium \\
\hline 9 & $\begin{array}{l}\text { The distraction of the student's thought as a result of not } \\
\text { clarifying the requirements of the course }\end{array}$ & 2.54 & 1.291 & 7 & Medium \\
\hline 10 & $\begin{array}{l}\text { Postpone the receipt of the required work from the } \\
\text { students on schedule }\end{array}$ & 2.50 & 1.287 & 9 & Medium \\
\hline 11 & $\begin{array}{l}\text { Gives absolute freedom to female students inside the } \\
\text { classroom }\end{array}$ & 2.73 & 1.290 & 3 & Medium \\
\hline 12 & Haven't the inability to properly plan lectures & 2.45 & 1.265 & $10 \mathrm{~s}$ & Medium \\
\hline- & Domain as a whole & 2.56 & 1.016 & - & Medium \\
\hline
\end{tabular}

It is clear from the results in the previous Table 7 that the general arithmetic average of the responses of the respondents to the paragraphs that measure the facilitative style has reached (2.56) and represents an average grade, and came first paragraph (1) (predominantly the character of personal compliments on University work account), followed by paragraph (2) (shirk responsibility in embarrassing situations with students), and in the last came paragraph (7) (hesitate to determine the dates of tests because I do not have the ability to make a decision), and I urged all the paragraphs that measure That area has low and medium estimates.

Results related to the second question: Are there significant differences at the level of significance $(\alpha \leq 0.05)$ between Among the averages for the response of the study sample to the prevailing leadership styles of the faculty members of the College of Education in Delam from the viewpoint of its students female Attributed to the variable (age, academic level, type of department)? 
Table 8. Arithmetic averages and standard deviations to identify the differences in the responses of the sample of the study towards the paragraphs of the study tool as a whole and its fields according to the age variable

\begin{tabular}{cccc}
\hline Description & Variable classes & Mean Arithmetic & $\begin{array}{c}\text { Standard } \\
\text { deviation }\end{array}$ \\
\hline \multirow{4}{*}{ Autocratic } & $18-21$ years & 2.74 & 0.742 \\
& $22-25$ years & 2.85 & 1.030 \\
& $26-29$ years & 2.18 & 0.833 \\
& 30 years and over & 2.19 & 0.421 \\
& & & \\
& $18-21$ years & 4.01 & 0.689 \\
Democratic & $22-25$ years & 3.99 & 0.772 \\
& $26-29$ years & 4.14 & 0.658 \\
& 30 years and over & 4.10 & 0.833 \\
Facilitative & $18-21$ years & 2.61 & 0.922 \\
& $22-25$ years & 2.65 & 1.132 \\
& $26-29$ years & 2.10 & 0.672 \\
The tool as a & 22-25 years & 1.70 & 0.776 \\
whole & $26-29$ years & 3.11 & 0.506 \\
& 30 years and over & 3.16 & 0.701 \\
& $18-21$ years & 2.79 & 0.389 \\
\hline
\end{tabular}

The results of the previous Table 8 show that there are obvious differences between the mean values of the responses of the sample towards the paragraphs of the study tool according to the age variable.

Table 9. The results of the analysis of the variance to identify the differences in the responses of the respondents towards the paragraphs of the study instrument as a whole and its fields according to age variable

\begin{tabular}{|c|c|c|c|c|c|c|}
\hline The style & $\begin{array}{l}\text { Contrast } \\
\text { source }\end{array}$ & $\begin{array}{l}\text { Sum of } \\
\text { Squares }\end{array}$ & DF & $\begin{array}{l}\text { Mean } \\
\text { squares }\end{array}$ & value $\mathrm{f}$ & Sig-f \\
\hline \multirow{3}{*}{ Autocratic } & $\begin{array}{l}\text { Between } \\
\text { groups }\end{array}$ & 12.645 & 3 & 4.215 & \multirow{3}{*}{$* 5.379$} & \multirow{3}{*}{0.001} \\
\hline & $\begin{array}{l}\text { During } \\
\text { groups }\end{array}$ & 231.950 & 296 & 0.784 & & \\
\hline & Total & 244.595 & 299 & & & \\
\hline \multirow{3}{*}{ Democratic } & $\begin{array}{l}\text { Between } \\
\text { groups }\end{array}$ & 0.562 & 3 & 0.187 & \multirow{3}{*}{0.354} & \multirow{3}{*}{0.787} \\
\hline & $\begin{array}{l}\text { During } \\
\text { groups }\end{array}$ & 156.793 & 296 & 0.530 & & \\
\hline & Total & 157.355 & 299 & & & \\
\hline \multirow{3}{*}{ Facilitative } & $\begin{array}{l}\text { Between } \\
\text { groups }\end{array}$ & 12.430 & 3 & 4.143 & \multirow{2}{*}{$* 4.138$} & \multirow{2}{*}{0.007} \\
\hline & $\begin{array}{l}\text { During } \\
\text { groups }\end{array}$ & 296.401 & 296 & 1.001 & & \\
\hline & Total & 308.831 & 299 & & \multirow{4}{*}{$* 4.353$} & \multirow{4}{*}{0.005} \\
\hline \multirow{3}{*}{$\begin{array}{c}\text { The tool as a } \\
\text { whole }\end{array}$} & $\begin{array}{l}\text { Between } \\
\text { groups }\end{array}$ & 4.531 & 3 & 1.510 & & \\
\hline & $\begin{array}{l}\text { During } \\
\text { groups }\end{array}$ & 102.699 & 296 & 0.347 & & \\
\hline & Total & 107.230 & 299 & & & \\
\hline
\end{tabular}

* Statistically significant at the level of significance $(\alpha \leq 0.05)$. 
The results of the previous Table 9 show that there are statistically significant differences between the mean values of the responses of the sample towards the paragraphs of the study tool according to the age variable on the tool as a whole and on the domains (autocratic style and the dropout style), depending on the significance of the calculated values of $(\mathrm{F})$ shown in The previous table at the significance level $(\alpha \leq 0.05)$. While the results in the previous table showed that there are no statistically significant differences on the field of (Democratic type) depending on the insignificance of the calculated value $(\mathrm{F})$ shown in the previous table. In order to identify the sources of differences, Xavier was tested for post-comparisons. The differences were as follows:

For the autocratic style, the differences were favorable for the two age groups (18-21 years, 22-25 years) at the expense of age group (26-29 years). The differences were statistically significant at the level of significance ( $\alpha \leq$ $0.05)$. For the democratic style, the differences were in favor of age groups (18-21 years, 22-25 years) at the expense of age groups (26-29 years, 30 years and above). For the tool as a whole, the differences were in favor of age groups (18-21 years, 22-25 years) at the expense of age groups (26-29 years, 30 years and above).

Table 10. The results of the Xavier test for dimensional comparisons to identify the sources of differences in the responses of the respondents to the tool as a whole and its fields (autocratic style, and the drop-off style) attributed to the age variable

\begin{tabular}{|c|c|c|c|c|}
\hline The style & Variable classes & Mean squares & $\begin{array}{l}\text { Difference in } \\
\text { favor }\end{array}$ & Average teams \\
\hline \multirow{6}{*}{ Autocratic } & $18-21$ years & 2.74 & - & - \\
\hline & $22-25$ years & 2.85 & - & - \\
\hline & \multirow{2}{*}{$26-29$ years } & \multirow{2}{*}{2.18} & \multirow{2}{*}{$\begin{array}{l}18-21 \text { years } \\
22-25 \text { years }\end{array}$} & $* 0.557$ \\
\hline & & & & $* 0.676 *$ \\
\hline & 30 years and & & & \\
\hline & over & 2.19 & - & - \\
\hline \multirow{6}{*}{ Facilitative } & $18-21$ years & 2.61 & - & - \\
\hline & $22-25$ years & 2.65 & - & - \\
\hline & \multirow{2}{*}{$26-29$ years } & \multirow{2}{*}{2.10} & $18-21$ years & $* 0.508$ \\
\hline & & & 22- 25 years & $* 0.550$ \\
\hline & 30 years and & \multirow{2}{*}{2.70} & $18-21$ years & $* 0.904$ \\
\hline & & & 22- 25 years & $* 0.945$ \\
\hline \multirow{6}{*}{$\begin{array}{c}\text { The tool as a } \\
\text { whole }\end{array}$} & $18-21$ years & 3.11 & - & - \\
\hline & $22-25$ years & 3.16 & - & - \\
\hline & \multirow{2}{*}{$26-29$ years } & \multirow{2}{*}{2.79} & $18-21$ years & \multirow{2}{*}{ - } \\
\hline & & & 22- 25 years & \\
\hline & \multirow{2}{*}{$\begin{array}{c}30 \text { years and } \\
\text { over }\end{array}$} & \multirow{2}{*}{2.65} & $18-21$ years & $* 0.318$ \\
\hline & & & 22- 25 years & $* 0.458$ \\
\hline
\end{tabular}

\footnotetext{
* Statistically significant at the level of significance $(\alpha \leq 0.05)$.
} 
Table 11. Arithmetic averages and standard deviations to identify the differences in the responses of the study sample towards the paragraphs of the study tool as a whole and its fields according to the level of study

\begin{tabular}{|c|c|c|c|}
\hline The style & Variable classes & Mean squares & Standard deviation \\
\hline \multirow{7}{*}{$\begin{array}{l}\text { Autocratic } \\
\text { Democratic }\end{array}$} & the first & 2.70 & 0.717 \\
\hline & The second & 3.02 & 0.880 \\
\hline & the third & 2.44 & 0.842 \\
\hline & the fourth & 2.68 & 0.970 \\
\hline & Fifth & 2.74 & 0.973 \\
\hline & VI & 2.93 & 1.008 \\
\hline & Seventh & 2.73 & 1.101 \\
\hline \multirow{9}{*}{$\begin{array}{l}\text { Facilitative } \\
\text { The tool as a whole }\end{array}$} & VIII & 2.49 & 0.861 \\
\hline & the first & 4.03 & 0.652 \\
\hline & The second & 4.13 & 0.716 \\
\hline & the third & 4.27 & 0.685 \\
\hline & the fourth & 3.54 & 0.819 \\
\hline & Fifth & 3.72 & 0.817 \\
\hline & VI & 4.10 & 0.716 \\
\hline & Seventh & 3.93 & 0.715 \\
\hline & VIII & 4.08 & 0.799 \\
\hline \multirow{7}{*}{$\begin{array}{l}\text { Autocratic } \\
\text { Democratic }\end{array}$} & the first & 2.58 & 0.922 \\
\hline & The second & 2.79 & 0.953 \\
\hline & the third & 2.29 & 0.798 \\
\hline & the fourth & 2.23 & 0.314 \\
\hline & Fifth & 2.80 & 1.046 \\
\hline & VI & 2.81 & 1.115 \\
\hline & Seventh & 2.54 & 1.182 \\
\hline \multirow{9}{*}{ Facilitative } & VIII & 2.17 & 0.997 \\
\hline & the first & 3.09 & 0.504 \\
\hline & The second & 3.30 & 0.616 \\
\hline & the third & 2.99 & 0.401 \\
\hline & the fourth & 2.81 & 0.281 \\
\hline & Fifth & 3.08 & 0.549 \\
\hline & VI & 3.27 & 0.739 \\
\hline & Seventh & 3.06 & 0.718 \\
\hline & VIII & 2.90 & 0.533 \\
\hline
\end{tabular}

The results of the previous Table 11 show that there are obvious differences between the mean values of the responses of the sample members towards the paragraphs of the study tool according to the study level variable. To determine whether these differences were statistically significant, One Way ANOVA was performed. The results are as follows: 
Table 12. The results of the analysis of the variance to identify the differences in the responses of respondents towards the paragraphs of the study tool as a whole and its fields according to the level of study.

\begin{tabular}{|c|c|c|c|c|c|c|}
\hline The style & $\begin{array}{c}\text { Contrast } \\
\text { source }\end{array}$ & $\begin{array}{l}\text { Sum of } \\
\text { Squares }\end{array}$ & $\mathrm{DF}$ & $\begin{array}{c}\text { Mean } \\
\text { squares }\end{array}$ & Value $\mathrm{f}$ & Sig-f \\
\hline \multirow{3}{*}{ Autocratic } & $\begin{array}{c}\text { Between } \\
\text { groups }\end{array}$ & 7.643 & 7 & 1.092 & \multirow{3}{*}{1.346} & \multirow{3}{*}{0.229} \\
\hline & $\begin{array}{l}\text { During } \\
\text { groups }\end{array}$ & 236.952 & 292 & 0.811 & & \\
\hline & Total & 244.595 & 292 & & & \\
\hline \multirow{3}{*}{ Democratic } & $\begin{array}{c}\text { Between } \\
\text { groups }\end{array}$ & 6.453 & 7 & 0.922 & \multirow{2}{*}{1.784} & \multirow{2}{*}{0.090} \\
\hline & $\begin{array}{l}\text { During } \\
\text { groups }\end{array}$ & 150.903 & 292 & 0.517 & & \\
\hline & Total & 157.355 & 299 & & \multirow{4}{*}{$* 2.043$} & \multirow{4}{*}{0.050} \\
\hline \multirow{3}{*}{ Facilitative } & $\begin{array}{c}\text { Between } \\
\text { groups }\end{array}$ & 14.420 & 7 & 2.060 & & \\
\hline & $\begin{array}{l}\text { During } \\
\text { groups }\end{array}$ & 294.411 & 292 & 1.008 & & \\
\hline & Total & 308.831 & 299 & & & \\
\hline \multirow{3}{*}{$\begin{array}{c}\text { The tool as a } \\
\text { whole }\end{array}$} & $\begin{array}{c}\text { Between } \\
\text { groups }\end{array}$ & 5.125 & 7 & 0.732 & \multirow{3}{*}{$* 2.094$} & \multirow{3}{*}{0.044} \\
\hline & $\begin{array}{l}\text { During } \\
\text { groups }\end{array}$ & 102.105 & 292 & 0.350 & & \\
\hline & Total & 107.230 & 292 & & & \\
\hline
\end{tabular}

* Statistically significant at the level of significance $(\alpha \leq 0.05)$.

The results of the previous Table 12 show that there are statistically significant differences between the mean values of the responses of the respondents towards the paragraphs of the study tool according to the level of study variable on the tool as a whole and on the field of (the Facilitative style), depending on the significance of the calculated values $(\mathrm{P})$ shown in the previous table. At the significance level $(\alpha \leq 0.05)$. While the results in the previous table showed that there are no statistically significant differences on the two domains (autocratic style, Democratic style) depending on the insignificance $(\mathrm{P})$ calculated value shown in the previous table.

For the democratic style, the differences in favor of the study levels (I, II, V, and VI) were calculated at the eighth level. The differences were statistically significant at the level of significance $(\alpha \leq 0.05)$. For the tool as a whole the differences were in favor of the study levels (second, sixth) at the expense of the levels (fourth, eighth), and the differences were statistically significant at the level of significance $(\alpha \leq 0.05)$. 
Table 13. The results of the Xavier test for comparisons after the identification of the sources of differences in the responses of the sample respondents to the tool as a whole and the field (the style of depreciation) attributed to the variable level of study

\begin{tabular}{|c|c|c|c|c|}
\hline The style & Variable classes & Mean squares & $\begin{array}{l}\text { Difference in } \\
\text { favor }\end{array}$ & Averages \\
\hline \multirow{8}{*}{ Facilitative } & the first & 2.58 & - & - \\
\hline & The second & 2.79 & - & - \\
\hline & the third & 2.29 & - & - \\
\hline & the fourth & 2.23 & - & - \\
\hline & Fifth & 2.80 & - & - \\
\hline & VI & 2.81 & - & - \\
\hline & Seventh & 2.54 & - & - \\
\hline & VIII & 2.17 & $\begin{array}{c}\text { The first } \\
\text { The second } \\
\text { The Fifth } \\
\text { VI }\end{array}$ & $\begin{array}{l}* 0.403 \\
* 0.615 \\
* 0.631 \\
* 0.637\end{array}$ \\
\hline \multirow{8}{*}{$\begin{array}{c}\text { The tool as a } \\
\text { whole }\end{array}$} & the first & 3.09 & - & - \\
\hline & The second & 3.30 & - & - \\
\hline & the third & 2.99 & - & - \\
\hline & the fourth & 2.81 & $\begin{array}{c}\text { The second } \\
\text { VI }\end{array}$ & \\
\hline & Fifth & 3.08 & - & - \\
\hline & VI & 3.27 & - & - \\
\hline & Seventh & 3.06 & - & - \\
\hline & VIII & 2.90 & $\begin{array}{c}\text { The second } \\
\text { VI }\end{array}$ & $\begin{array}{l}* 0.401 \\
* 0.369\end{array}$ \\
\hline
\end{tabular}

* Statistically significant at the level of significance $(\alpha \leq 0.05)$.

Table 14. Arithmetic averages and standard deviations to identify the differences in the responses of the sample of the study towards the paragraphs of the study tool as a whole and its fields according to the type of section

\begin{tabular}{cccc}
\hline The style & Variable classes & Mean squares & Standard deviation \\
\hline \multirow{3}{*}{ Autocratic } & Mathematics & 2.88 & 0.956 \\
& Home Economics & 2.31 & 1.016 \\
& Islamic studies & 2.85 & 0.794 \\
& Arabic Language & 2.55 & 0.970 \\
& Mathematics & 3.82 & 0.845 \\
Democratic & Home Economics & 4.12 & 0.774 \\
& Islamic studies & 3.98 & 0.688 \\
& Arabic Language & 4.17 & 0.685 \\
Facilitative & Mathematics & 2.69 & 0.988 \\
& Home Economics & 1.99 & 0.879 \\
& Islamic studies & 2.74 & 0.971 \\
& Arabic Language & 2.37 & 1.077 \\
& Mathematics & 3.12 & 0.556 \\
The tool as a whole & Home Economics & 2.79 & 0.559 \\
& Islamic studies & 3.18 & 0.586 \\
& Arabic Language & 3.02 & 0.623 \\
\hline
\end{tabular}


The results of the previous Table 14 show that there are obvious differences between the mean values of the responses of the respondents towards the paragraphs of the study tool according to the type of department.

\begin{tabular}{|c|c|c|c|c|c|c|}
\hline The style & $\begin{array}{c}\text { Contrast } \\
\text { source }\end{array}$ & $\begin{array}{l}\text { Sum of } \\
\text { Squares }\end{array}$ & $\mathrm{DF}$ & $\begin{array}{c}\text { Mean } \\
\text { squares }\end{array}$ & value $\mathrm{f}$ & Sig-f \\
\hline \multirow{3}{*}{ Autocratic } & $\begin{array}{c}\text { Between } \\
\text { groups }\end{array}$ & 11.819 & 3 & 3.940 & \multirow{3}{*}{$* 5.009$} & \multirow{2}{*}{0.002} \\
\hline & $\begin{array}{l}\text { During } \\
\text { groups }\end{array}$ & 232.777 & 296 & 0.786 & & \\
\hline & Total & 244.595 & 299 & & & \\
\hline \multirow{3}{*}{ Democratic } & $\begin{array}{l}\text { Between } \\
\text { groups }\end{array}$ & 3.671 & 3 & 1.224 & \multirow{3}{*}{2.357} & \multirow{3}{*}{0.072} \\
\hline & $\begin{array}{l}\text { During } \\
\text { groups }\end{array}$ & 153684 & 296 & 0.519 & & \\
\hline & Total & 157.355 & 299 & & & \\
\hline \multirow{3}{*}{ Facilitative } & $\begin{array}{l}\text { Between } \\
\text { groups }\end{array}$ & 19.748 & 3 & 6.583 & \multirow{3}{*}{$* 6.740$} & \multirow{2}{*}{0.000} \\
\hline & $\begin{array}{l}\text { During } \\
\text { groups }\end{array}$ & 289.083 & 296 & 0.977 & & \\
\hline & Total & 308.831 & 299 & & & \multirow{4}{*}{0.003} \\
\hline \multirow{3}{*}{$\begin{array}{c}\text { The tool as a } \\
\text { whole }\end{array}$} & $\begin{array}{l}\text { Between } \\
\text { groups }\end{array}$ & 4.893 & 3 & 1.631 & \multirow{3}{*}{$* 4.718$} & \\
\hline & $\begin{array}{l}\text { During } \\
\text { groups }\end{array}$ & 102337 & 296 & 0.346 & & \\
\hline & Total & 107.230 & 299 & & & \\
\hline
\end{tabular}

* Statistically significant at the level of significance $(\alpha \leq 0.05)$.

The results of the previous Table 15 show that there are statistically significant differences between the mean values of the responses of the respondents towards the paragraphs of the study tool according to the type of division on the tool as a whole and on the domains (autocratic style and negligence style), depending on the significance of the calculated values of $(\mathrm{P})$. In the previous table at the significance level $(\alpha \leq 0.05)$. There were no differences according to the type of division on the field of the democratic type depending on the significant $(\mathrm{P})$ value shown in the previous table at the significance level $(\alpha \leq 0.05)$. In order to identify the sources of differences, a test was conducted for Xavier dimensional comparisons, the differences were as follows:

For the autocratic style, the differences were in favor of mathematics at the expense of home economics, and in favor of Islamic studies at the expense of my specialty: (home economics, Arabic language) The mean difference D was statistically significant at $\alpha \leq 0.05$. For the Facilitative style, the differences were in favor of mathematics at the expense of home economics, and in favor of Islamic studies at the expense of my specialty: (home economics, Arabic language) the mean difference $\mathrm{D}$ was statistically significant at $\alpha \leq 0.05$. For the tool as a whole, the differences were in favor of my specialty: mathematics and Islamic studies at the expense of home economics. The mean difference was statistically significant at the level of significance $(\alpha \leq 0.05)$. 
Table 16. The results of the Xavier test for dimensional comparisons to identify the sources of differences in the responses of the sample respondents to the tool as a whole and their fields (autocratic style, and the drop-off style) are attributed to the type of section variable

\begin{tabular}{|c|c|c|c|c|}
\hline The style & $\begin{array}{l}\text { Variable } \\
\text { classes }\end{array}$ & Mean squares & $\begin{array}{l}\text { Difference in } \\
\text { favor }\end{array}$ & Average teams \\
\hline \multirow{5}{*}{ Autocratic } & Mathematics & 2.88 & - & - \\
\hline & & \multirow{2}{*}{2.31} & Mathematics & $* 0573$ \\
\hline & $\begin{array}{l}\text { Home } \\
\text { Economics }\end{array}$ & & Islamic studies & $* 0.545$ \\
\hline & Islamic studies & 2.85 & - & - \\
\hline & $\begin{array}{c}\text { Arabic } \\
\text { Language }\end{array}$ & 2.55 & Islamic studies & $* 0.301$ \\
\hline \multirow{5}{*}{ Facilitative } & Mathematics & 2.69 & - & - \\
\hline & Home & \multirow{2}{*}{1.99} & Mathematics & *0.697 \\
\hline & Economics & & Islamic studies & $* 0.749$ \\
\hline & Islamic studies & 2.74 & - & - \\
\hline & $\begin{array}{c}\text { Arabic } \\
\text { Language }\end{array}$ & 2.37 & Islamic studies & $* 0.367$ \\
\hline \multirow{5}{*}{$\begin{array}{c}\text { The tool as a } \\
\text { whole }\end{array}$} & Mathematics & 3.12 & - & - \\
\hline & Home & \multirow{2}{*}{2.79} & & $* 0.332$ \\
\hline & Economics & & Islamic studies & $* 0390$ \\
\hline & Islamic studies & 3.18 & - & - \\
\hline & $\begin{array}{c}\text { Arabic } \\
\text { Language }\end{array}$ & 3.02 & - & - \\
\hline
\end{tabular}

* Statistically significant at the level of significance $(\alpha \leq 0.05)$.

\section{Conclusion}

The results showed that the general arithmetic mean of the responses of the respondents to the paragraphs that measure the prevailing leadership styles of the faculty members at the College of Education in Delam from the point of view of its female students came with a medium degree of appreciation. The democratic style came first, followed by the second, the autocratic, and finally the Facilitative. This result means that faculty members practice leadership styles to a moderate degree from the perspective of students. The democratic style shows that it has been ranked first and this means faculty members' keenness to take into consideration the needs of the students, their objectivity and flexibility in dealing with them, avoiding prejudice, opening the door for dialogue and participation, accepting objective criticism, enhancing confidence and instilling values of cooperation, friendliness, love and others. With regard to the autocratic style, it has received an average appreciation by the students, which demonstrates the commitment of faculty members of the students to study plans and test dates and some procedures that are understood by the students as orders and learning limit the freedom and expression. As for the Facilitative style, it came in last place according to the level of importance for the respondents. This means that the faculty members in some situations are predominantly personal courtesy and evade responsibility in embarrassing situations and rely on students to explain some parts of lectures and lack of interest in some cases. The result is consistent with the Ford (1998) study, the results of which showed the prevalence of three types of leadership: Democracy, concessional, and authoritarianism, and the results of the study (Giambri, 2003), which showed that there are styles of leadership to clarify the tasks before the participants, The result also met with the study (Ashour, 2012), which showed that the leadership style practiced by the heads of departments at the Yarmouk University is the democratic leadership style and to a large extent, followed by the authoritarian leadership and a medium degree, and then came the style of permissive leadership and a medium degree. The result was also in line with the study (Cremin, 2013), which found that the level of academic leaders' skills of leadership behavior was moderate. The result also coincided with a study (Al-Shatnawi and Al-Ghamdi, 2016), whose results showed that the leadership style prevailing among academic 
department heads was democratically and in practice. The results of the study (Tahtouh, 2016), which showed many of the results, including more than the style of democratic leadership, It also differed with the results of the study (Arabiyat, 2012), which showed a trace of the democratic style and Tzipi, and the results of the study are lagging behind the study (Bani Issa and Al-Attari, 2019) which showed that the facilitative style is the most effective one.

The results showed that there were statistically significant differences between the mean values of the responses of the sample towards the paragraphs of the study tool according to the age variable on the tool as a whole. The differences were in favor of the age groups (18-21 years, 22-25 years) at the expense of the age groups (26-29 years, 30 years and above). As for the tool as a whole, the differences were in favor of the two age groups (18-21 years, 22-25 years) at the expense of the two age groups (2). 6-29 years, 30 years and over), This means that younger students have slightly different views than their older counterparts. The results also showed that there are no statistically significant differences in the field of (democratic style) due to the age variable, meaning that students from different age groups agree that the teaching staff practice the democratic style, The result is consistent with Brown (1999), which showed differences due to age variations in the study sample 's perception of the type of effective leadership.

The results indicated that there were statistically significant differences between the mean values of the responses of the respondents towards the paragraphs of the study tool according to the level of study variable on the tool as a whole, and on the field of (the drop-off style). At the expense of the eighth academic level, for the instrument as a whole the differences were in favor of the academic levels (II, VI) at the expense of the academic levels (IV, VIII). The differences indicate the differences in the views of female students at lower levels and differ from those at higher levels. This may be due to their more experience with faculty members practicing the Tzipi style. It refers to the variable level of study and this means the consensus of the views of the students researched towards the Paragraphs, which measures the typical (autocratic and democratic), She concurs with the results of Brown (1999) that there are no differences due to the variable of experience, which corresponds to the years of the level of study as a study experience for female students in the college for the current study.

Finally, the results showed that there were statistically significant differences between the mean values of the responses of the respondents towards the paragraphs of the study tool according to the type of division on the tool as a whole, and on the domains (autocratic style and the tsetse style). At the expense of home economics, and for the benefit of Islamic studies at the expense of specialization: (home economics, Arabic language), and this result is consistent with the study (Crimin, 2013) the existence of differences due to the specialization associated with a particular section to the extent of leaders possess the skills of leadership behavior, As for the tool as a whole, the differences were in favor of my specialty: mathematics and Islamic studies at the expense of home economics. The results also showed that there are no differences due to the type of department variable on the field of democratic style, and the result is consistent with the absence of above attributed to the college variable in a study (Bani Issa and Al-Attari, 2019)

\section{Recommendations}

Based on the previous results, the study makes the following recommendations foe the faculty members as well as the academic institutions:

1. Urge the university faculty members to practice the democratic leadership style and to avoid the practice of the authoritarian leadership style and the facilitative leadership style.

2. Hold training courses and workshops periodically to familiarize faculty members with positive leadership styles to work and practice, and negative leadership styles and away from the introduction or practice.

3. Working on creating an Arab Islamic administrative leadership model that fits with the culture, values and beliefs of the society like American model and the Japanese model, while benefiting from the leadership sciences in the developed societies through the establishment of a leadership styles research centers.

4. Conducting more scientific studies similar to the subject of the current study in other universities in Saudi Arabia to benefit from its results and disseminate its recommendations. 


\section{References}

Abdul Khaliq, Abdul Khaliq, \& Ali, Muhammad. (2009). Administration and Educational Planning. Third Edition, Al-Mutanabi Library, Saudi Arabia: Dammam.

Al-Shatnawi, Nawaf Mousa, \& Al-Ghamdi, Noura Jamaan. (2016). The prevailing leadership style among department heads at Al-Baha University, International Journal of Education. International Interdisciplinary Journal of Education, 1(7), 1-17. https://doi.org/10.12816/0036061

Al-Taweel, Yani Abdul Rahman. (1999). The Educational Administration. Amman: Dar Wael for Printing and Publishing

Arabeyat, Bashir. (2012). The prevailing styles of educational leadership among the heads of academic departments at Al-Balqa Applied University, and its impact on the job performance of faculty members College of Technology Engineering Case Study. Journal of the Islamic University for Educational and Psychological Studies, 20(2), 706-736.

Bani Issa Iman, \& Al-Atari, Aref. (2019). Styles of behavior of leaders as recognized by faculty members working in universities in northern Jordan and their link to some variables. Al-Quds Open University Journal for Educational and Psychological Research and Studies, 10(27), 194-208.

Brown,Clay Eugene. (1999). A comparative study of public college and university presidential perceptions of eggective leadership practices. ERIC Documents, ED NO.9840279.

Dahish, Khaled, Al-Shallash, Abdul-Rahman, \& Radwan, Sami. (2006). Educational Administration and Planning Fundamentals of Theory and Practical Applications. Second Edition. Al-Rushd Library: Riyadh

Ford, M. E. (1998). Educational Administration and Organizational Behavior, Behavior, Boston, Allyn and Bacon Inc

Fred C.Lunenburg. (2011). Leadership Versus Management: At Least In Theory. International Journal of Management, Business, \& Administration, $14(1), \quad 2 . \quad$ Published in: https://cs.anu.edu.au/courses/comp3120/localdocs/readings/Lunenburg LeadershipVersusManagement.pdf

Giambri, Lynn. (2003). Administrator and Staff Perception of the Leadership Role in the Effective Operationalization of the Mission of the 21st Century Christian School, Dissertation Abstract International, $D A I-A, 64 / 03$, P. 737.

John H.Zenger, \& Joseph R.Folkman. (2009). The Extraordinary Leader: Turning Good Managers into Great leaders, McGraw-Hill Publisher, New York, pp 213-229.

Jorslav Gonso, \& Peter Gallo. (2013). Model For Leadership Style Evaluation, Management, 18, 161-163. published in: https://www.efst.hr/management/Vol18No2-2013/10-Gonos_Gallo.pdf

Karimin, Hani Ahmed. (2013). The level of academic leaders at Tafila Technical University possess the skills of leadership behavior from the perspective of faculty members. International Interdisciplinary Journal of Education, 1(1037), 1-31: https://doi.org/10.12816/0002937

Mahjoub, Basman. (2003). The leading role of college deans in Arab universities. The Arab Administrative Development Organization, Cairo, Egypt

Tahtouh, Aley. (2016). The Impact of Managerial Leadership Styles on Organizational Citizenship Behavior (An Empirical Study on Female Employees at King AbdulAziz University in Jeddah) Unpublished Master Thesis, Faculty of Economics and Management King Abdulaziz University in Jeddah 